\title{
Maatalousopiskelijoiden työharjoitteluprosessin tehostaminen maatiloilla virtuaalisesti
}

Ari Sivula $^{1)}$, Eliisa Kallio' ${ }^{2)}$ ja Juhani Suojaranta ${ }^{3)}$

${ }^{1)}$ SeAMK Elintarvike ja maatalous, Kalevankatu 35, 60100 Seinäjoki, Ari.Sivula@ seamk.fi

${ }^{2)}$ SeAMK Elintarvike ja maatalous, Ilmajoentie 525, 60800 Ilmajoki, Eliisa.Kallio@ seamk.fi

${ }^{3)}$ SeAMK Elintarvike ja maatalous, Ilmajoentie 525, 60800 Ilmajoki, Juhani.Suojaranta@ seamk.fi

\section{Tiivistelmä}

Työharjoittelu on oleellinen osa maaseutuelinkeinojen ammattikorkeakouluopintoja, jossa opiskelija tutustuu opiskelemaansa alaan. Nykypäivän kehitystrendi on mobiiliteknologia, josta on hyötyä opiskelijoiden työharjoitteluprosessissa. Oikein toteutettuna mobiilisovellukset ovat nopeita, yksinkertaisia ja helppokäyttöisiä.

Virtuaalimaatilat-oppimisympäristöllä tuetaan maatalousopiskelijoiden työharjoitteluprosessia. Opiskelijalla on mahdollista tutustua maatiloihin virtuaalisessa muodossa ennen työharjoittelun alkua. Harjoittelun aikana opiskelija täyttää harjoitteluraporttinsa oppimisympäristöön mobiilisti, jolloin ohjaaja näkee reaaliajassa työharjoittelun etenemisen ja tieto pysyy ajantasaisena ympäristössä sekä nopeuttaa harjoitteluraportin koostamista tavoitteiden mukaisesti. Lisäksi opiskelija voi hyödyntää tilatietoja opiskelun aikaisten harjoitustehtävien lähdemateriaalina. Oppilaitoksessa tehdyt tehtävät voivat hyödyntää myös tiloja tuotannon suunnittelussa.

Työharjoitteluohjaajat sekä opiskelijat välittävät tietoa muun muassa harjoittelun sujumisesta työharjoittelun aikana. Hankkeessa toteutetaan myös tietovirtakuvaus, jossa selviää työharjoitteluprosessin tietovirrat. Oppimisympäristö ja tietovirtaselvitys toteutetaan Virtuaalimaatilojen kehittämishankkeessa.

\section{Asiasanat}

Mobiiliympäristöt, mobiilioppiminen, oppimisympäristö, tietovirrat, virtuaalinen oppiminen

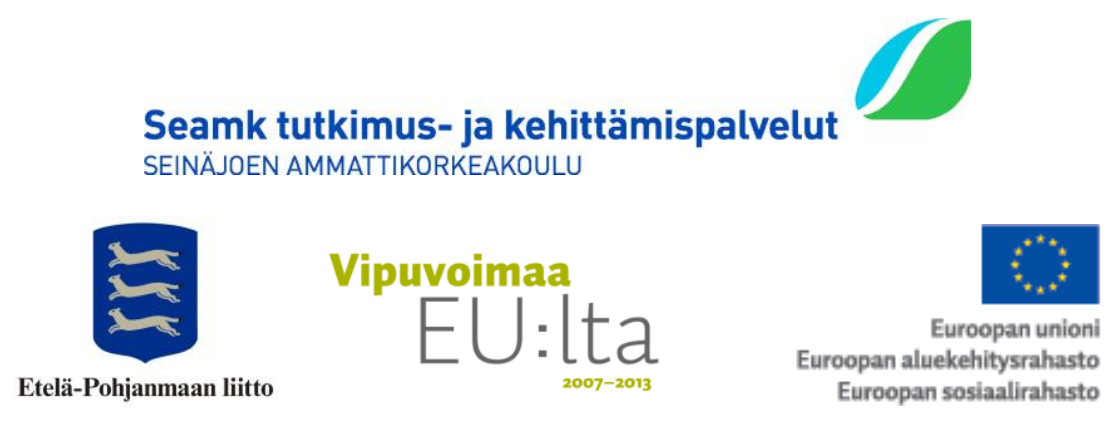




\section{Johdanto}

Työharjoittelu on oleellinen osa opintoja ja se antaa käytännön kokemusta opiskellusta alasta (SeAMK 2013). SeAMK Elintarvike ja maataloudessa harjoittelu jakautuu kahteen erilliseen harjoittelujaksoon maatila- ja erikoistumisharjoitteluun. Maatilaharjoittelu tehdään yksikön kanssa sopimuksen tehneillä harjoittelutiloilla. Harjoittelutilat antavat todellisen kuvan maataloudesta tämän päivän laajentuvilla ja kehittyvillä tiloilla. Erikoistumisharjoittelu voidaan tehdä muun muassa maataloushallinnon, kaupan ja neuvonnan työtehtävissä. Laaja raportointi on perinteisesti liittynyt maatilaharjoitteluun. Oppimisympäristöllä voidaan oleellisesti tehostaa työharjoitteluun liittyvää raportointia.

Oppimisympäristöjä on olemassa sekä fyysisiä että virtuaalisia. Fyysinen oppimisympäristö on lähtökohtaisesti tila, missä opetus fyysisesti tapahtuu, esimerkiksi luokkahuone tai laboratorio (Scholastic 2013). Oppimisympäristö voi olla myös fyysinen demola, jossa esitetään esimerkiksi koneen tai laitteen, kuten lämpölaitoksen, toimintaa (Sivula, Lauhanen, Saarela, Ahtola \& Pasila 2013: 19). Tässä julkaisussa perehdytään virtuaalisen oppimisympäristön hyödyntämiseen maatalousopiskelijoiden työharjoittelussa.

Virtuaaliset oppimisympäristöt (engl. Virtual Learning Environment) on tunnistettu olevan etäoppimisen mahdollistava työkalu (Greasley 2004: 975). Kasvotusten tehdyt kontaktit vähenevät ohjaajan kanssa. Oppiminen on erilaista kuin perinteinen oppiminen. Virtuaaliset oppimisympäristöt soveltuvat työharjoittelun oppimisympäristöiksi, sillä kontakti harjoitteluohjaajan tai opettajan kanssa on vähäisempää työharjoittelun aikana. Oikein hyödynnettynä virtuaaliset oppimisympäristöt mahdollistavat ajasta ja paikasta riippumattoman opiskelun.

Virtuaalimaatilat tehostavat opiskelijan, maatilan harjoitteluohjaajien sekä ohjaavien opettajien välistä vuorovaikusta. Virtuaalimaatilojen mobiilisovellus tarjoaa tavan nopeaan kommunikaatioon kolmen osapuolen välillä, mutta eritoten opiskelijan ja ohjaajan välillä. Virtuaalimaatilojen tietoja on mahdollista hyödyntää ennen ja jälkeen työharjoittelun erilaisissa maatalousalan harjoitustöissä. Seinäjoen ammattikorkeakoulussa kehitettyä mallia on mahdollista hyödyntää myös muissa Suomen ammattikorkeakouluissa sekä eri toimialoilla.

\section{Työharjoittelu}

Opiskelijat tekevät maatilaharjoittelun ensimmäisen opiskeluvuoden kesällä Suomessa tai ulkomailla. Harjoitteluaika sijoittuu touko-syyskuulle ja kestää maksimissaan 95 työpäivää. Harjoittelu tehdään oppilaitoksen hyväksymällä tilalla. Maatilaharjoittelu vahvistaa käytännön taitoja ja antaa kuvan koko kasvukauden työvaiheista. (SeAMK 2013).

Nykyiset harjoittelutilat antavat todellisen kuvan tämän päivän kehittyvistä ja laajentuvista maatiloista. Tällaisten tilojen johtajuuteen ja yrittäjyyteen ammattikorkeakoulujen sekä yliopistojen tulisi opiskelijoita kouluttaa ja opettaa tuntemaan. Työharjoitteluprosesseja sekä niihin liittyviä malleja sekä järjestelmiä tulisi kehittää sekä niihin tulisi kohdistaa monenlaista poikkitieteellistä tutkimusta. Tiedon liikkuvuus on vähäistä pienen kontaktimäärän vuoksi työharjoittelun aikana. Opiskelijaa ei tavata päivittäin työharjoittelun aikana. Tästä syystä erilaiset kehittämistoimet parantavat tiedon vaihtoa maatilaharjoitteluohjaajien, opiskelijoiden sekä ohjaavien opettajien välillä. 


\section{Virtuaalimaatilat työharjoittelun tukena}

Kehitystrendi nykypäivänä korkeakoulutuksessa on selkeä. Opiskelijat pitäisi pystyä saamaan työelämään mahdollisimman nopeasti sekä tehokkaasti. Virtuaaliset oppimisympäristö toimivat oppimisen tukena sekä mahdollistavat oppimisen monimediaisella tavalla. Virtuaaliset oppimisympäristöt mahdollistavat paikasta ja ajasta riippumattoman oppimisen (Keski-Mattinen, Niskanen \& Sivula 2011: 5). Työharjoittelu on myös oppimista ja sitä on mahdollista tehostaa näin ollen virtuaalisilla oppimisympäristöillä.

Virtuaalimaatiloilla tehostetaan kolmen toimijan kommunikaatiota: ohjaajavan opettajan, opiskelijan sekä maatilaohjaajan. Virtuaalimaatilat nykyaikaistavat työharjoitteluraportoinnin. SeAMK Elintarvike ja maataloudessa on aiemmin raportoitu paperilla. Virtuaalimaatilat mahdollistavat raportoinnin sähköisesti ja mobiilisti. Sidosryhmien edustajilla on erilaiset oikeudet ympäristöön. Ohjaajalla on vahvimmat oikeudet, opiskelijat näkevät perustietoja sekä oman raporttinsa. Maatilaohjaajilla on oikeudet omaan maatilaansa ja heillä on oikeus nähdä oman maatilansa tiedot raportteineen.

Ympäristö jakautuu kolmeen eri osaan, joita ovat verkko- ja mobiiliosa sekä rajapinnat, joilla tiedon vaihto suoritetaan eri osien välillä. Kuvassa 1 on esitetty Virtuaalimaatilojen ympäristökuvaus yleisellä tasolla.

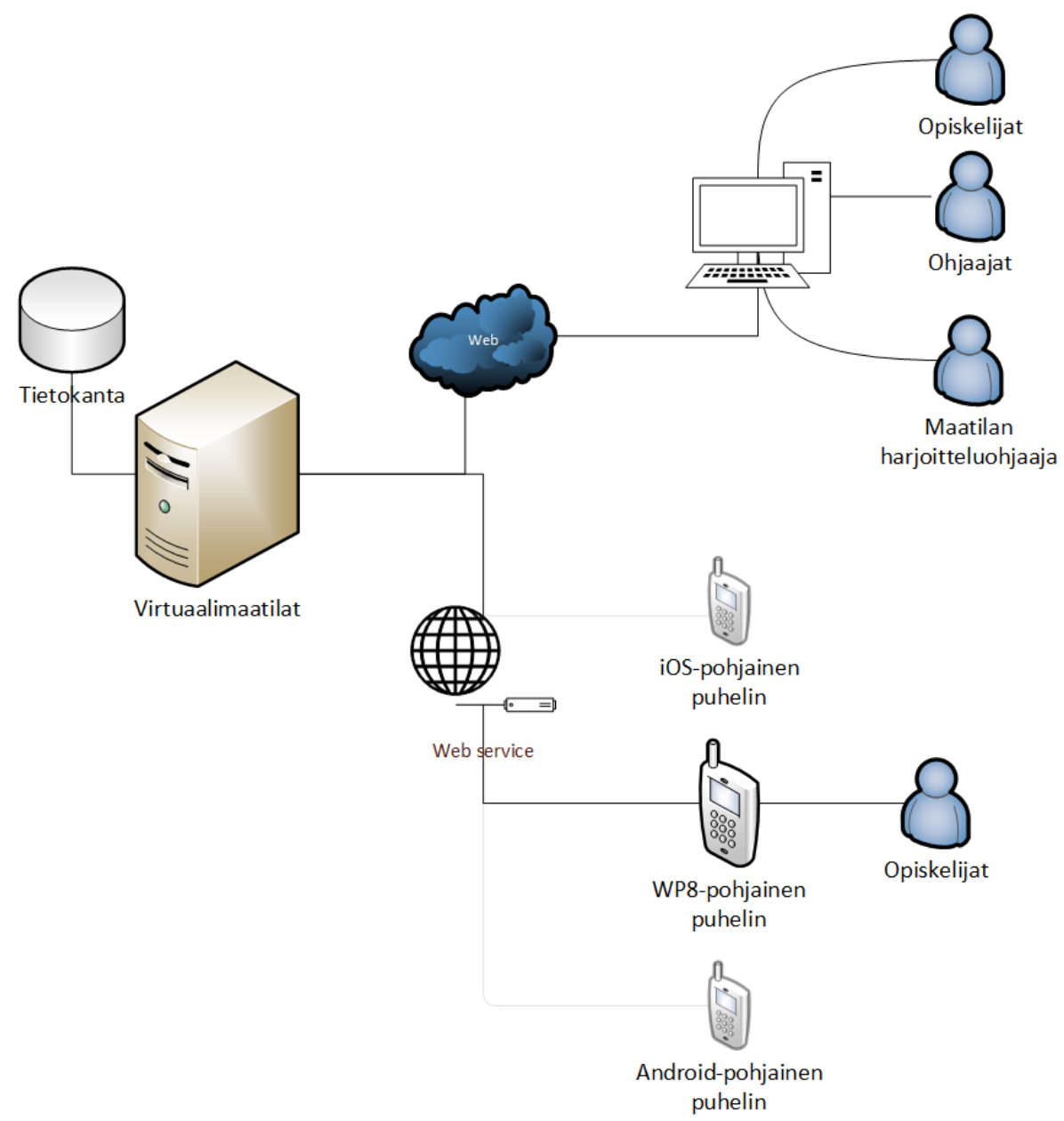

Kuva 1. Ympäristökuvaus yleisellä tasolla. 
Web-rajapinnat toimivat tiedon ja datan välittäjinä sekä mobiili- että web-sovellukselle. Virtuaalimaatilojen kehittämishankkeessa toteutetaan Windows Phone 8 (WP8) -pohjainen mobiilisovellus, jolla opiskelijat hyödyntävät oppimisympäristöä. Oppimisympäristö on mahdollista laajentaa myös iOS- ja Androidpohjaisiin puhelimiin mobiilipohjaista verkkosovellusta unohtamatta. Oppimisympäristössä tietoturva on huomioitu käyttäjätunnistein sekä roolituksin perustuen oppimisympäristön käyttäjiin.

Virtuaalimaatilat-oppimisympäristössä kuvilla on keskeinen rooli. Mobiililaitteen selkeä hyöty on sen pieni koko, mutta huonojakin puolia löytyy (Keski-Mattinen, Niskanen \& Sivula 2011: 37). Mobiililaitteella on hankalaa kirjoittaa pitkiä raportteja. Tästäkin syystä oppimisympäristössä hyödynnetään kuvia monella tavalla tekstin tukena. Oppimisympäristön pohjana on hyödynnetty SeAMK Elintarvike ja maatalouden toteuttamaan työharjoitteluraporttia, joka on yksinkertaistettu sekä mallinnettu oppimisympäristöön.

Alkuperäisestä harjoitteluraportista tehtiin viisi suurempaa kokonaisuutta oppimisympäristöön, joita ovat maatilan perustiedot, kasvituotanto, kotieläintuotanto, metsätalous sekä yritystoiminta. Opiskelijat raportoivat oppimisympäristön osa-alueisiin etukäteen määritettyihin alakohtiin tietoja muun muassa maatilan koneista, tuotantorakennuksista, kasveista, kylvöstä, sadonkorjuusta sekä kasvinsuojelusta. Työharjoittelu on laaja oppimiskokonaisuus, minkä vuoksi myös raportoitava kokonaisuus on laaja. Oppimisympäristö antaa mahdollisuuden opiskelijalle kertoa asioista myös suppeasti kuvien vuoksi. Lisäksi oppimisympäristö sisältää kaikki tarpeelliset liitteet, kuten sopimukset sekä lohkokortin, jotka tulee täyttää käsin oppimisen sekä allekirjoitusten vuoksi.

\section{Pohdinta ja johtopäätökset}

Virtuaalimaatilat-oppimisympäristö on tällä hetkellä kehitysvaiheessa, mutta siitä on jo saatu ensimmäiset käyttökokemukset. Opiskelijat sekä ohjaajat kokevat ympäristön käytännöllisenä sekä hyvänä tapana toteuttaa raportointi. Raportointi tulee tehdä sillä hetkellä, kun asiat maatilalla tapahtuvat. Oppiminen on tämä vuoksi sujuvampaa. Ohjaava opettaja näkee maatilan tapahtumat reaaliaikaisesti. Samoin tilan väki voi kommentoida opiskelijan tekemiä havaintoja ja toimenpide-ehdotuksia esimerkiksi kasvi- ja kotieläintuotannon eri hoitotoimenpiteissä. Oppimisympäristö antaa mahdollisuuden lisätä vuorovaikutteisuutta tilojen, oppilaitoksen ja opiskelijoiden välillä.

Opiskelija koostaa harjoitteluraporttia havainnollistamalla tilan eri työvaiheita valokuvilla ja täydentää kuvien sisällöt kertomalla niissä esiintyvät asiat. Menetelmä antaa mahdollisuuden raportoida tehokkaasti harjoittelun aikana eteen tulevista käytännön oppimistilanteista ja samalla harjaannuttaa opiskelijaa ratkomaan ongelmatilanteita. Vuosien kuluessa tilan tapahtumista kertyy laaja tietopankki, jota eri osapuolet voivat hyödyntää. Ammattikorkeakoulun opiskelijat voivat hyödyntää eritoten myöhemmissä opinnoissa tilalta kerättyä tietovarastoa erilaisten suunnitelmien lähdeaineistona ja tilat voivat hyödyntää niitä myöhemmin tilojensa kehittämistyössä. Aineisto voi tiloilla toimia myös dokumentteina kesän tapahtumista EU:n edellyttämää seurantaa toteutettaessa.

Oppimisympäristön kehittäminen maatilaharjoittelutilojen kanssa antaa jatkossa mahdollisuuden laajentaa käytäntöä myös erikoistumisharjoittelun raportoinnissa. Tällöin yhteistyökumppaneina ovat yritykset, joissa opiskelija on tekemässä harjoitteluaan. Tiedonkeruun onnistuminen mobiilisti voi antaa myös mahdollisuutta hyödyntää menetelmää maatilojen tuotannon laadunvalvonnassa. 


\section{Lähteet}

Greasley, K. 2004. A virtual learning environment for operations management: Assessing the student's perspective. Teoksessa: International Journal of Operations \& Production Management; 2004; 24, 9/10; ProQuest: 974 s.

Keski-Mattinen, T., Niskanen, J. \& Sivula, A. 2011. Ammattikorkeakouluopintojen ohjaus etätyömenetelmillä. Seinäjoki: Seinäjoen ammattikorkeakoulu. ISBN: 978-952-5863-23-9

Scholastic. 2013. Classroom Organization: The Physical Environment. Viitattu 25.11.2013. Saatavilla World Wide Webistä <URL: http://www.scholastic.com/teachers/article/classroom-organizationphysical-environment>

SeAMK. 2013. Harjoittelu. Viitattu 25.11.2013. Saatavilla World Wide Webistä <URL: http://www.seamk.fi/Suomeksi/Koulutus/Koulutusalat/Luonnonvara--jaymparistoala/Maaseutuelinkeinojen-koulutusohjelma/Harjoittelu>

Sivula, A., Lauhanen, R., Saarela, A., Ahtola, T., \& Pasila, A. 2013. Bioenergia-asiantuntijuutta kehittämässä Etelä-Pohjanmaalla. ISBN: 978-952-5863-49-9 